\title{
ELECTROPHORETIC ANALYSIS OF SERUM PROTEIN IN REITER'S SYNDROME
}

\author{
BY \\ GEORGE W. CSONKA \\ Physician to the Medical Research Council Investigation of Non-Specific Urethritis
}

AND

E. KAWERAU

St. Mary's Hospital, London

Reiter's syndrome is a condition of unknown aetiology, but is probably of infective origin, with the primary focus in the genital tract. It occurs characteristically in young men in association with non-specific urethritis, arthritis, and conjunctivitis. In the course of time other features were noted to be sometimes associated, including haemorrhagic cystitis, iritis, sacro-iliitis, ankylosing spondylitis, balanitis, stomatitis, keratoderma blenorrhagica, and other skin lesions. Formes frustes are also recognized, of which the combination of nonspecific urethritis and arthritis alone is the commonest. The natural history of these clinical types of the syndrome appears to be essentially the same (Csonka, 1958).

The attacks are usually of acute onset and of a few months duration, but recurrences or relapses are common and in some cases the condition becomes sufficiently severe and chronic to be mistaken for rheumatoid arthritis.

This paper is concerned with the electrophoretic pattern of serum proteins obtained in thirty consecutive male patients with Reiter's syndrome. As a control, the sera of 27 healthy medical students and ten cases of rheumatoid arthritis were examined by the same method.

In the patients with Reiter's syndrome, the protein estimations were repeated at different stages of the disease; the remainder had single tests. None of the patients with Reiter's syndrome had albuminuria and there was no evidence of liver disease. Although there is, as yet, no specific treatment for this condition, all the patients were having treatment with one of the broadspectrum antibiotics and analgesics, four were having phenylbutazone. Fever therapy or steroids were only given after the specimens had been obtained for electrophoresis. None of the patients with rheumatoid arthritis were on cortisone treatment when the electrophoresis of the serum proteins was undertaken.

\section{Method}

The total protein was determined by the biuret method, results being read from a standard graph on which the biuret values for total protein had been checked by Kjeldahl N determinations. Electrophoresis was carried out in the Bridge Unit described by Kawerau (1954). Satisfactory resolution of alpha-one globulin from albumin was obtained in every case. It has been our experience that apparatus of different design, e.g. vertical tanks, does not give such a satisfactory separation in this region. A rigid technique giving an overall separation of 13-14 cm. was adhered to in the course of this investigation. It has been shown by Kohn (1957) that separation of alpha-one globulin from albumin is much improved on cellulose acetate strips, but unfortunately this material was not available when this work was begun. Quantitative evaluation of the electropherograms was undertaken after the strips had been rendered translucent by impregnation with benzyl alcohol and by photo-electric scanning of 1-mm. cross-sections of the strips with the apparatus described by Grassman, Hannig, and Knedel (1951). The protein areas of the graphs so obtained were measured with the planimeter, and each one was expressed as a percentage of the total area. Absolute values for the globulin fractions were not calculated from the relative percentage figures, as there is some objection to this procedure (Durrum, 1956), and in this particular investigation it would not have increased the accuracy of the calculations significantly, for the total protein values in the groups that were compared varied only over a narrow range. 


\section{Results}

Characteristic electropherograms are shown in Fig. 1. The sera belong to patients who suffered an exacerbation of the chronic form of the respective illnesses. The high alpha globulins in Reiter's syndrome and the high gamma globulin in rheumatoid arthritis are the most distinguishing features. The pattern for Reiter's syndrome often looks more dramatically abnormal than it appears here, but this choice has been deliberate in order to emphasize the difficulty inherent in the technique. Casual inspection may not reveal the abnormality. A protein spread of over $13-14 \mathrm{~cm}$. is required and careful planimetric evaluation is needed before significant alterations in the alpha-one proteins can be detected. It must be emphasized here that investigators employing different apparatus and technique may not obtain comparable results. When results by different techniques are compared, the determining factor is the total distance that the albumin travelled (on account of albumin training), the sharpness of resolution, and the type of dye used for the staining. As this communication is not primarily intended for a discussion of the technique of paper electrophoresis, the reader is referred to the bibliography for further information.

Table I and Fig. 2 (opposite) summarize the statis- $\frac{\mathrm{O}}{\mathrm{N}}$ tical analysis of the results, assuming that the distribution of the normal concentration of the protein fractions follows a normal distribution curve, and that therefore 95 per cent. of all normal values will lie 드 within a range of two standard deviations (S.D.) above and below the mean volume for each fraction. To estimate whether the mean of the protein fractions from Reiter's patients differs significantly from the mean of the control group, the " $t$ " test is used. A value of 5 per cent. has been selected as level of significance, i.e. values of greater magnitude would occur by chance only once in twenty times.

As the results are expressed as percentage of total protein, a change in one fraction will lead to complementary changes in the percentage distribution of all other fractions; thus a decreased concentration $\underset{\mathcal{V}}{ }$ of albumin results in an increased percentage of 0 all globulin fractions, and an abnormal increase in a particular globulin fraction can only be considered 0 under these circumstances, if it exceeds the expected rise, or total protein is increased.

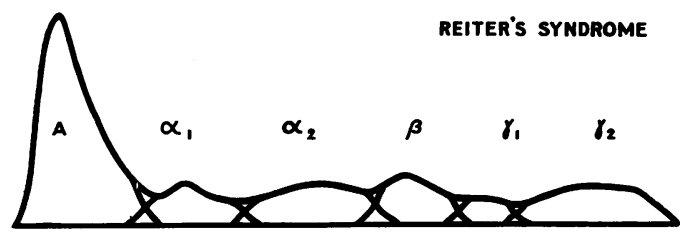

\begin{tabular}{cr} 
Protein & Percentage \\
\hline A & 50.6 \\
$\alpha_{1}$ & 9.4 \\
$\alpha_{2}$ & 16.4 \\
$\beta$ & 6.9 \\
$\gamma_{1}$ & 5.4 \\
$\gamma_{2}$ & 11.3
\end{tabular}

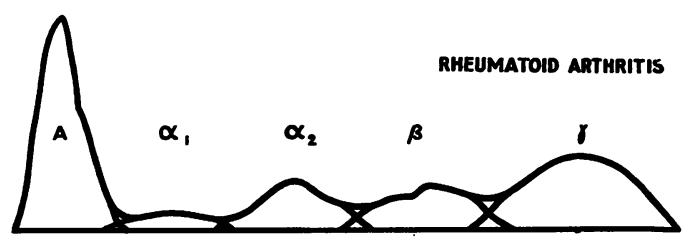

$\begin{array}{lr}\text { A } & 40.4 \\ \alpha_{1} & 3.4 \\ \alpha_{2} & 11.8 \\ \beta & 13.2 \\ \gamma & 31.2\end{array}$

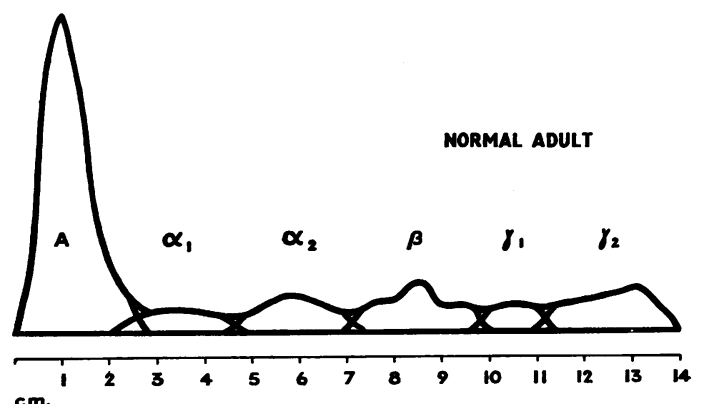

$\begin{array}{lr}A & 64.0 \\ \alpha_{1} & 4.9 \\ \alpha_{2} & 10.3 \\ \beta & 9.1 \\ \gamma_{1} & 3.3 \\ \gamma_{2} & 8.4\end{array}$


ELECTROPHORETIC ANAL YSIS OF SERUM PROTE IN IN REITER'S SYNDROME 431

ELECTROPHORETIC SERUM PROTEIN FRACTIONS IN REITER'S SYNDROME AND HEALTHY CONTROLS

\begin{tabular}{|c|c|c|c|c|c|c|c|c|c|c|c|c|}
\hline \multirow{2}{*}{\multicolumn{4}{|c|}{ Series }} & \multirow{2}{*}{\multicolumn{2}{|c|}{$\begin{array}{c}\text { No. } \\
\text { of } \\
\text { Patients }\end{array}$}} & \multirow{3}{*}{ 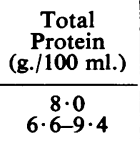 } & \multirow{3}{*}{$\begin{array}{c}\begin{array}{c}\text { Albumin } \\
(\% \text { Total } \\
\text { Protein) }\end{array} \\
\begin{array}{c}63 \cdot 8 \\
52 \cdot 8-74 \cdot 8\end{array}\end{array}$} & \multicolumn{5}{|c|}{ Globulin ( $\%$ Total Protein) } \\
\hline & & & & & & & & \multirow{2}{*}{$\frac{\alpha_{1}}{\frac{3 \cdot 8}{1 \cdot 2-6 \cdot 4}}$} & \multirow{2}{*}{$\frac{\alpha_{2}}{7 \cdot 0} \frac{2 \cdot 6-11 \cdot 4}{2 \cdot 4}$} & \multirow{2}{*}{$\frac{\beta}{10 \cdot 6} \frac{6 \cdot 0-15 \cdot 2}{6}$} & \multirow{2}{*}{ 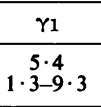 } & \multirow{2}{*}{$\frac{\gamma_{2}}{4 \cdot 9 \cdot 4}$} \\
\hline Controls & $\cdots$ & $\cdots$ & $\cdots$ & 27 & $\begin{array}{l}\text { Mean } \\
\pm 2 \text { S.D. }\end{array}$ & & & & & & & \\
\hline Reiter's S & rome & $\cdots$ & $\cdots$ & 30 & $\begin{array}{l}\text { Mean } \\
\text { Signif. }(p)\end{array}$ & $\begin{array}{l}7 \cdot 4 \\
\text { Nil }\end{array}$ & $\begin{array}{c}48 \cdot 3 \\
0 \cdot 001\end{array}$ & $\begin{array}{l}7 \cdot 3 \\
0 \cdot 001\end{array}$ & $\begin{array}{c}12 \cdot 1 \\
0 \cdot 001\end{array}$ & $\begin{array}{c}13 \cdot 5 \\
0 \cdot 01\end{array}$ & $\begin{array}{l}6.9 \\
0.05\end{array}$ & $\begin{array}{c}12 \cdot 3 \\
0.01\end{array}$ \\
\hline
\end{tabular}

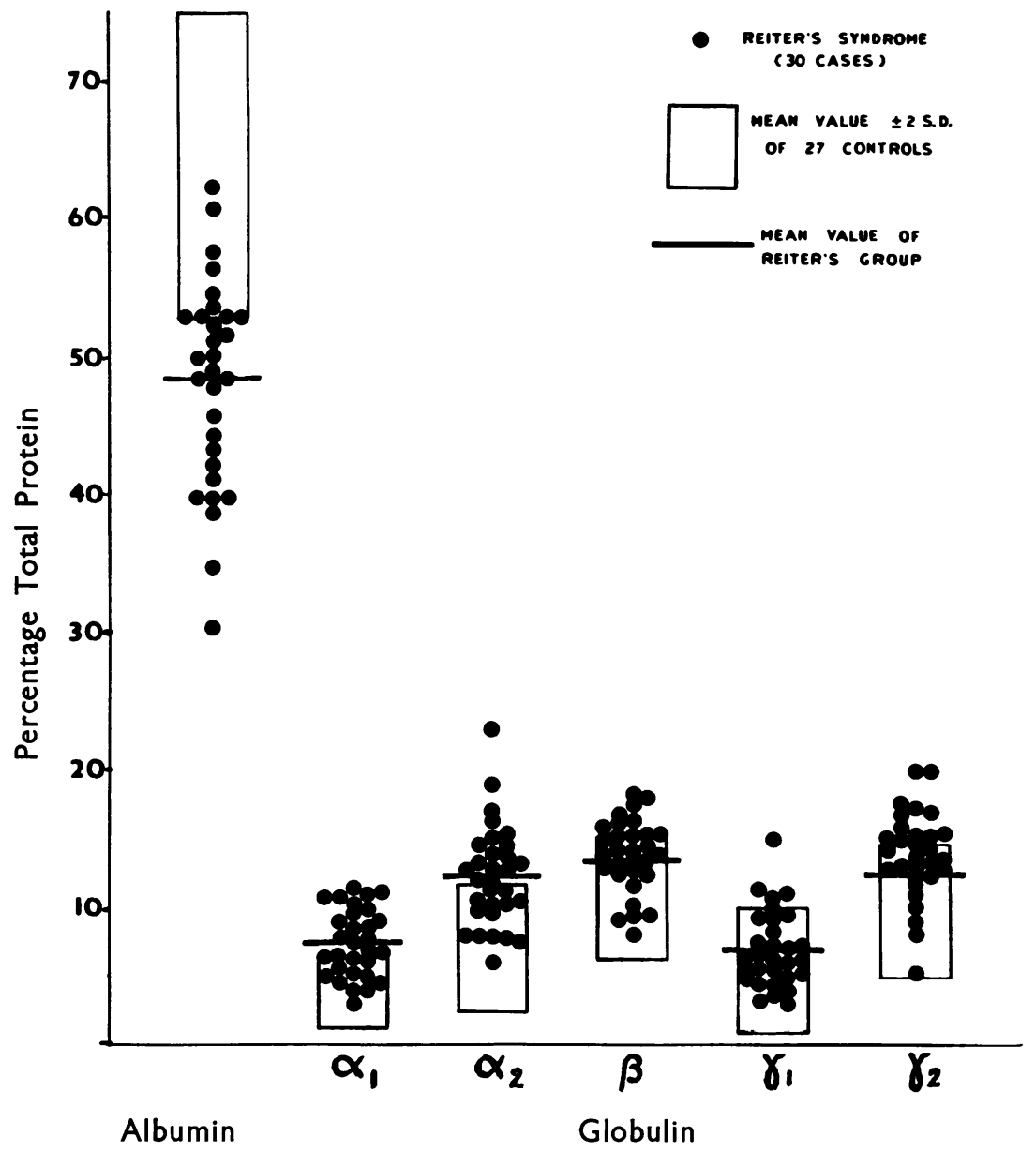

Fig. 2.

The total protein of the Reiter's patients did not significantly differ from the control group. A significant degree of hypo-albuminaemia was found in 24 of the thirty patients and was at the lower level of the normal range in the remaining six. Of the globulin fractions, $\alpha_{1}$ was significantly raised in nineteen cases and was at the upper limit of the normal range in three; $\alpha_{2}$ was significantly raised in eighteen cases with five more at the upper limit of normal. The $\beta$ globulin showed a less marked 
rise, which affected ten sera. The $\gamma_{1}$ and $\gamma_{2}$ globulins were significantly raised in five and twelve sera respectively.

In Table II the cases are separated according to the clinical severity and activity of the illness. The changes in the protein fractions in the severe cases are more marked than in the less severe ones, but in both groups the direction of these changes from the normal is the same, i.e. towards hypo-albuminaemia, raised $\alpha$ and $\gamma$ globulins, and a less constant increase in the other globulins. The third group consisted of patients judged to be convalescent when the protein fractions were estimated; the main abnormalities were a decrease in albumin and an increase in the globulin concentration, but these changes were smaller than in the other groups which contained the active cases.

An analysis of the protein pattern according to the duration of the syndrome, which ranged from one week to several years, showed no significant changes related to duration, provided due regard to clinical severity was made; thus a long but mild attack produced protein changes similar to those seen in a short but mild attack, and a severe attack was commonly associated with the more marked changes in the albumin and $\alpha$ globulin fractions, irrespective of its duration.

\section{Serial Electrophoretic Serum Protein Estimations}

In fourteen cases of Reiter's syndrome the tests were repeated at different times during the illness. 36 sera were examined and significant hypoalbuminaemia and raised globulin concentration were seen to be present as early as the seventh day after the onset of arthritis (or the sixteenth day of urethritis). These changes were slow to return towards normal after the attack was over, and in one case the abnormalities were still present one year after the acute attack had subsided. Of particular interest were four chronic cases, which were, at one time, thought to suffer from rheumatoid arthritis.
Serial tests were performed over a period of 8 to 23 months; the results are shown with representative examples of other patients in Table III (opposite). This corroborates the impression formed from single estimations in patients taken at different phases of the illness, and shows that the changes in the protein fractions are correlated with the severity rather than with the duration of the disease, and that these abnormalities are reasonably constant over a period of time and distinct from those generally accepted as characteristic for rheumatoid arthritis (see Discussion).

Correlation with the Erythrocyte Sedimentation Rate

The erythrocyte sedimentation rate (Westergren) was estimated simultaneously with the serum electrophoresis (Table IV, opposite). Correlation between the E.S.R. and electrophoretic protein changes was good, but a few discrepancies occurred. Correlation between these tests and the clinical status was best in the group of cases judged to be severely affected. Both the raised E.S.R. and the abnormal protein pattern were independent of body temperature.

The group of patients with rheumatoid arthritis was not analysed in great detail, on account of their small number. The clinical history of these patientso showed, however, that one was dealing with alf stages of the disease, with respect both to the durae tion and to the severity of the illness. The significant rise in gamma globulins in this group of patients, as compared with that in the Reiter's syndrome group, is not a chance finding, as the statistical analysis shows (Table V, opposite).

\section{Discussion}

There is scanty information in the medical literature on the electrophoretic serum protein fractions in Reiter's syndrome. Svartz and Olhagen (1948) found an increase in alpha globulin and a

TABLE II

MEAN ELECTROPHORETIC VALUES IN THIRTY CASES OF REITER'S SYNDROME, BY CLINICAL SEVERITY AND ACTIVITY OF DISEASE

\begin{tabular}{|c|c|c|c|c|c|c|c|c|c|c|}
\hline \multirow{2}{*}{\multicolumn{3}{|c|}{ Clinical Group }} & \multirow{2}{*}{\multicolumn{2}{|c|}{ No of Patients }} & \multirow{3}{*}{$\begin{array}{c}\begin{array}{c}\text { Albumin } \\
\text { (per cent.) }\end{array} \\
\begin{array}{c}42 \cdot 7 \\
31 \cdot 3-54 \cdot 1\end{array}\end{array}$} & \multicolumn{5}{|c|}{ Globulin (per cent.) } \\
\hline & & & & & & \multirow{2}{*}{$\frac{\alpha_{1}}{4 \cdot 0-6}$} & \multirow{2}{*}{$\frac{\alpha_{2}}{7 \cdot 6-21 \cdot 0}$} & \multirow{2}{*}{$\frac{\beta}{14 \cdot 1}$} & \multirow{2}{*}{$\frac{\gamma_{1}}{1 \cdot 6 \cdot 8}$} & \multirow{2}{*}{$\frac{\gamma_{2}}{12 \cdot 6} \frac{6 \cdot 9-18 \cdot 3}{6 \cdot 3}$} \\
\hline Severe $\ldots$ & $\cdots$ & $\cdots$ & 14 & $\begin{array}{l}\text { Mean } \\
\pm 2 \text { S.D. }\end{array}$ & & & & & & \\
\hline Mild & $\cdots$ & $\cdots$ & 9 & $\begin{array}{l}\text { Mean } \\
\pm 2 \text { S.D. }\end{array}$ & $\begin{array}{c}52 \cdot 4 \\
43 \cdot 5-61 \cdot 3\end{array}$ & $\begin{array}{l}6 \cdot 9 \\
3 \cdot 7-10 \cdot 1\end{array}$ & $\begin{array}{c}11 \cdot 2 \\
5 \cdot 4-17 \cdot 0\end{array}$ & $\begin{array}{c}11 \cdot 7 \\
5 \cdot 6-17 \cdot 8\end{array}$ & $\begin{array}{c}6 \cdot 1 \\
4 \cdot 8-7 \cdot 4\end{array}$ & $\begin{array}{l}11 \cdot 9 \\
3 \cdot 1-20 \cdot 7\end{array}$ \\
\hline Convalescent & $\ldots$ & $\cdots$ & 7 & $\begin{array}{l}\text { Mean } \\
\pm 2 \text { S.D. }\end{array}$ & $\begin{array}{c}54 \cdot 4 \\
47 \cdot 9-60 \cdot 9\end{array}$ & $\begin{array}{c}5 \cdot 2 \\
1 \cdot 8-8 \cdot 6\end{array}$ & $5 \cdot 6-12 \cdot 2$ & $\begin{array}{l}13 \cdot 8 \\
9 \cdot 2-18 \cdot 4\end{array}$ & $\begin{array}{c}5 \cdot 8 \\
1 \cdot 3-14 \cdot 3\end{array}$ & $\begin{array}{l}12 \cdot 0 \\
8 \cdot 0-16 \cdot 0\end{array}$ \\
\hline
\end{tabular}


TABLE III

SERIAL ELECTROPHORETIC PROTEIN TESTS IN SEVEN CASES OF REITER'S SYNDROME

\begin{tabular}{|c|c|c|c|c|c|c|c|c|c|}
\hline \multirow{3}{*}{$\begin{array}{l}\text { Case } \\
\text { No. }\end{array}$} & \multirow{3}{*}{$\begin{array}{l}\text { Date } \\
\text { of } \\
\text { Test }\end{array}$} & \multirow{3}{*}{ Clinical Status } & \multirow{3}{*}{$\begin{array}{c}\text { Erythrocyte } \\
\text { Sedimentation } \\
\text { Rate } \\
\text { (mm./hr } \\
\text { Westergren) }\end{array}$} & \multicolumn{6}{|c|}{ Serum Protein Fractions (per cent.) } \\
\hline & & & & \multirow{2}{*}{ Albumin } & \multicolumn{5}{|c|}{ Globulin } \\
\hline & & & & & $\alpha_{1}$ & $\alpha_{2}$ & $\beta$ & $\gamma_{1}$ & $\gamma_{2}$ \\
\hline 1 & $\begin{array}{l}10.4 .56 \\
8.10 .56\end{array}$ & $\begin{array}{l}\text { Acute severe attack of } 2 \text { weeks' duration } \\
\text { End of convalescence; fit to work }\end{array}$ & $\begin{array}{r}30 \\
5\end{array}$ & $\begin{array}{l}47 \cdot 7 \\
54 \cdot 5\end{array}$ & $\begin{array}{r}10 \cdot 1 \\
4 \cdot 5\end{array}$ & $\begin{array}{l}12 \cdot 7 \\
10 \cdot 0\end{array}$ & $\begin{array}{l}15 \cdot 2 \\
15 \cdot 2\end{array}$ & $\begin{array}{l}3 \cdot 6 \\
4 \cdot 8\end{array}$ & $\begin{array}{l}10 \cdot 7 \\
11 \cdot 0\end{array}$ \\
\hline 2 & $\begin{array}{l}23.3 .56 \\
19.6 .57\end{array}$ & $\begin{array}{l}\text { Acute severe attack of one week's duration } \\
\text { Symptom-free one year after end of attack }\end{array}$ & $\begin{array}{r}108 \\
5\end{array}$ & $\begin{array}{l}49 \cdot 6 \\
50 \cdot 6\end{array}$ & $\begin{array}{l}4 \cdot 9 \\
9 \cdot 4\end{array}$ & $\begin{array}{l}18 \cdot 9 \\
16 \cdot 4\end{array}$ & $\begin{array}{r}13 \cdot 2 \\
6 \cdot 9\end{array}$ & $\begin{array}{l}4 \cdot 9 \\
5 \cdot 4\end{array}$ & $\begin{array}{r}8 \cdot 5 \\
11 \cdot 3\end{array}$ \\
\hline 3 & $\begin{array}{r}12.10 .56 \\
29.10 .56 \\
17.7 .57 \\
23.8 .57\end{array}$ & $\begin{array}{l}\text { Acute mild attack of } 10 \text { days' duration } \\
\text { Improving } \\
\text { Symptom-free for } 8 \text { months } \\
\text { Recurrence of arthritis lasting one week }\end{array}$ & $\begin{array}{r}32 \\
14 \\
5 \\
30\end{array}$ & $\begin{array}{l}46 \cdot 0 \\
46 \cdot 3 \\
51 \cdot 8 \\
44 \cdot 2\end{array}$ & $\begin{array}{l}9 \cdot 7 \\
5 \cdot 0 \\
7 \cdot 0 \\
8 \cdot 1\end{array}$ & $\begin{array}{r}14 \cdot 7 \\
15 \cdot 2 \\
9 \cdot 6 \\
13 \cdot 8\end{array}$ & $\begin{array}{l}12 \cdot 8 \\
13 \cdot 5 \\
11 \cdot 9 \\
17 \cdot 0\end{array}$ & $\begin{array}{l}4 \cdot 4 \\
7 \cdot 6 \\
4 \cdot 1 \\
6 \cdot 0\end{array}$ & $\begin{array}{l}12 \cdot 4 \\
12 \cdot 4 \\
15 \cdot 6 \\
10 \cdot 9\end{array}$ \\
\hline 4 & $\begin{array}{l}16.3 .56 \\
14.6 .57 \\
21.3 .58\end{array}$ & $\begin{array}{l}\text { Chronic severe illness; duration } 15 \text { years; } \\
\text { at present quiescent } \\
\text { Greatly increased activity } \\
\text { Improving; slight activity in joints }\end{array}$ & $\begin{array}{r}4 \\
15 \\
12\end{array}$ & $\begin{array}{l}57 \cdot 6 \\
42 \cdot 0 \\
56 \cdot 5\end{array}$ & $\begin{array}{l}4 \cdot 4 \\
8 \cdot 5 \\
5 \cdot 8\end{array}$ & $\begin{array}{l}11 \cdot 1 \\
13 \cdot 9 \\
11 \cdot 8\end{array}$ & $\begin{array}{l}12 \cdot 9 \\
14 \cdot 0 \\
10 \cdot 2\end{array}$ & $\begin{array}{l}4 \cdot 2 \\
9 \cdot 1 \\
4 \cdot 7\end{array}$ & $\begin{array}{r}9 \cdot 9 \\
12 \cdot 5 \\
11 \cdot 0\end{array}$ \\
\hline 5 & $\begin{array}{r}3.3 .56 \\
10.4 .57\end{array}$ & $\begin{array}{l}\text { Chronic mild illness; duration } 12 \text { years } \\
\text { Improving; slight activity in joints }\end{array}$ & $\begin{array}{r}20 \\
6\end{array}$ & $\begin{array}{l}54 \cdot 5 \\
51 \cdot 1\end{array}$ & $\begin{array}{l}4 \cdot 0 \\
5 \cdot 5\end{array}$ & $\begin{array}{l}9 \cdot 1 \\
8 \cdot 8\end{array}$ & $\begin{array}{l}13 \cdot 3 \\
16 \cdot 8\end{array}$ & $\begin{array}{l}7 \cdot 1 \\
6 \cdot 9\end{array}$ & $\begin{array}{l}12 \cdot 0 \\
11 \cdot 0\end{array}$ \\
\hline 6 & $\begin{array}{r}28.12 .55 \\
1.2 .56 \\
16.11 .56 \\
25.1 .57 \\
8.7 .57 \\
6.1 .58\end{array}$ & $\begin{array}{l}\text { Acute severe attack of } 2 \text { months' duration } \\
\text { Slight improvement } \\
\text { Joints still active } \\
\text { No change } \\
\text { Joints better; iritis troublesome } \\
\text { Sacro-iliitis radiologically confirmed; } \\
\text { joints active }\end{array}$ & $\begin{array}{r}135 \\
103 \\
52 \\
50 \\
60 \\
15\end{array}$ & $\begin{array}{l}39 \cdot 8 \\
36 \cdot 9 \\
38 \cdot 5 \\
35 \cdot 3 \\
51 \cdot 0 \\
54 \cdot 3\end{array}$ & $\begin{array}{l}4 \cdot 1 \\
6 \cdot 2 \\
6 \cdot 2 \\
7 \cdot 6 \\
6 \cdot 8 \\
7 \cdot 5\end{array}$ & $\begin{array}{l}12 \cdot 7 \\
13 \cdot 4 \\
14 \cdot 5 \\
14 \cdot 6 \\
10 \cdot 9 \\
13 \cdot 4\end{array}$ & $\begin{array}{l}13 \cdot 2 \\
12 \cdot 4 \\
16 \cdot 2 \\
19 \cdot 5 \\
12 \cdot 9 \\
10 \cdot 0\end{array}$ & $\begin{array}{r}10 \cdot 1 \\
7 \cdot 0 \\
9 \cdot 2 \\
7 \cdot 9 \\
5 \cdot 1\end{array}$ & $\begin{array}{l}20 \cdot 1 \\
24 \cdot 0 \\
15 \cdot 4 \\
15 \cdot 1 \\
13 \cdot 3\end{array}$ \\
\hline 7 & $\begin{array}{r}19.10 .56 \\
1.11 .56 \\
29.5 .57\end{array}$ & $\begin{array}{l}\text { Chronic severe illness; duration } 13 \text { years } \\
\text { No change } \\
\text { Activity increasing; new joints involved }\end{array}$ & $\begin{array}{l}50 \\
19 \\
20\end{array}$ & $\begin{array}{l}47 \cdot 0 \\
43 \cdot 0 \\
34 \cdot 5\end{array}$ & $\begin{array}{r}5 \cdot 3 \\
6 \cdot 5 \\
11 \cdot 2\end{array}$ & $\begin{array}{r}8 \cdot 2 \\
13 \cdot 5 \\
13 \cdot 6\end{array}$ & $\begin{array}{r}14 \cdot 6 \\
14 \cdot 4 \\
9 \cdot 5\end{array}$ & $\begin{array}{r}6 \cdot 1 \\
5 \cdot 5 \\
14 \cdot 8\end{array}$ & $\begin{array}{l}18 \cdot 4 \\
17 \cdot 1 \\
16 \cdot 4\end{array}$ \\
\hline
\end{tabular}

TABLE IV

ERYTHROCYTE SEDIMENTATION RATE AND SERUM PROTEIN CHANGES

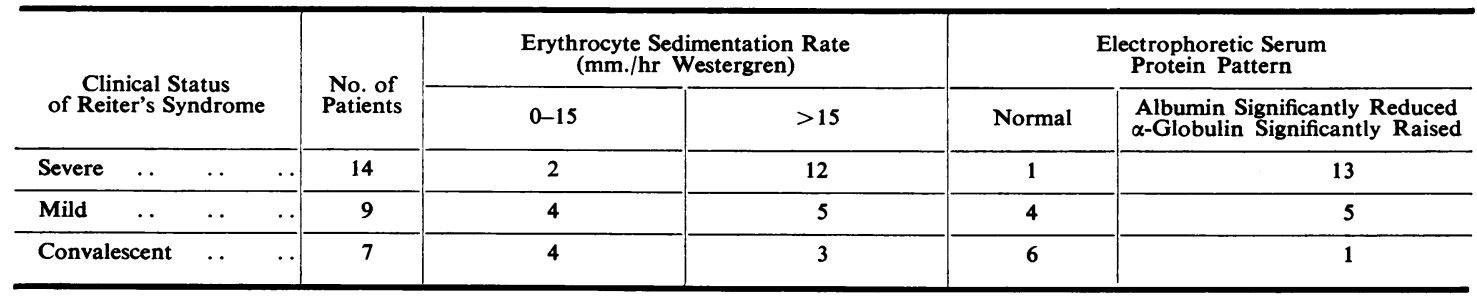

TABLE $V$

ELECTROPHORETIC SERUM PROTEIN FRACTIONS IN REITER'S SYNDROME AND RHEUMATOID ARTHRITIS

\begin{tabular}{|c|c|c|c|c|c|c|c|c|c|}
\hline \multirow{2}{*}{\multicolumn{2}{|c|}{ Series }} & \multirow{2}{*}{\multicolumn{2}{|c|}{$\begin{array}{c}\text { No. } \\
\text { of } \\
\text { Patients }\end{array}$}} & \multirow{3}{*}{$\frac{\begin{array}{c}\text { Total } \\
\text { Protein } \\
\text { (g./100 ml.) }\end{array}}{} \frac{\begin{array}{c}7 \cdot 4 \\
5 \cdot 8-9 \cdot 0\end{array}}{}$} & \multirow{3}{*}{$\begin{array}{c}\begin{array}{c}\text { Albumin } \\
\text { (per cent.) }\end{array} \\
\begin{array}{c}48 \cdot 3 \\
33 \cdot 9-62 \cdot 7\end{array}\end{array}$} & \multicolumn{4}{|c|}{ Globulin (per cent.) } \\
\hline & & & & & & \multirow{2}{*}{$\frac{\alpha_{1}}{7 \cdot 3} \frac{7 \cdot 6 \cdot 0}{2 \cdot 6 \cdot 0}$} & \multirow{2}{*}{$\frac{\alpha_{2}}{5 \cdot 0-19 \cdot 2}$} & \multirow{2}{*}{$\begin{array}{c}\beta \\
\begin{array}{c}13 \cdot 5 \\
7 \cdot 9-19 \cdot 1\end{array}\end{array}$} & \multirow{2}{*}{$\frac{\gamma^{*}}{19 \cdot 0} \frac{8 \cdot 4-29 \cdot 6}{}$} \\
\hline Reiter's Syndrome & $\cdots$ & 30 & $\begin{array}{l}\text { Mean } \\
\pm 2 \text { S.D. }\end{array}$ & & & & & & \\
\hline Rheumatoid Arthritis & $\cdots$ & 10 & $\begin{array}{l}\text { Mean } \\
\text { Signif. }(p)\end{array}$ & $\begin{array}{l}7 \cdot 6 \\
\mathrm{Nil}\end{array}$ & $\begin{array}{c}41 \cdot 1 \\
5 \text { per cent. }\end{array}$ & $6 \cdot 4$ & $12 \cdot 4$ & $12 \cdot 5$ & $28 \cdot 0$ \\
\hline
\end{tabular}

* Expressed as $\gamma$-globulin, as not every serum in rheumatoid arthritis could be separated into $\gamma_{1}$ and $\gamma_{2}$ globulin.

decrease in albumin concentration in three such patients. Ropes, Perlmann, Kaufman, and Bauer (1954) found similar changes in two cases, and Laurell (1956) reported a significant increase in the alpha-two globulin in the presence of low albumin concentration in three cases. Our observations are in agreement with those of these authors.
Of the 23 patients with active disease, nineteen showed a significant rise in the alpha globulins, which was slightly more marked in the alpha-one fractions. That this increase in the alpha proteins is due to an increase of glycoproteins was shown by Laurell (1956), who determined the hexose content of the alpha proteins in his cases of Reiter's syn- 
drome. Serum alpha-two glycoprotein increases have been shown by Stary, Bodur, and Batiyok (1951) and by Jayle (1946) to move parallel with the E.S.R. A similar parallelism has been observed in our cases. Jayle has gone further and linked E.S.R. increases with rises in the alpha-two haptoglobulin glycoprotein of serum in various forms of disease. Whether or not the alpha-two globulin increases in Reiter's syndrome are synonymous with raised haptoglobulin levels remains, at present, uncertain, and may be a problem worthy of further investigation.

Recent studies in the clinical interpretation of quantitative paper electrophoresis (Antweiler, 1957; Jencks, Smith, and Durrum, 1956) show that the combination of low albumin and high alpha globulins, with little change in the other globulin fractions, is not a specific pattern for Reiter's syndrome, as similar changes have been noted in many other conditions, mainly infectious. It is evident from this study, however, that, though the pattern may not be specific, it is characteristic for Reiter's syndrome and persists at least as long as the disease can be judged on clinical grounds to be active. Sera obtained months or even years after urethral and eye symptoms have subsided show the characteristic electrophoretic protein changes, and there is, therefore, no evidence that the protein changes depend on the persistence of the genital infection.

In the diagnosis of Reiter's syndrome, rheumatoid arthritis has sometimes to be considered. Some authorities, in fact, have suggested that one may be dealing with rheumatoid arthritis which has been precipitated by the genital infection (Hench and Boland, 1946; Hench and others, 1948; Balboni and Kydd, 1952). It is therefore of interest to compare our findings in Reiter's syndrome with the recent literature on the serum proteins in rheumatoid arthritis.

Two main patterns have been described:

(1) Raised alpha and gamma globulin (Svartz and Olhagen, 1948; Wallis, 1950; Ropes and others, 1954; Hunt and Trew, 1954; Laurell, 1956; Bonomo, 1957).

(2) Raised gamma globulin as the outstanding or sole globulin abnormality (Browning, Rice, and Ulrich, 1951; Layani, Bengui, and Mende, 1952; Olhagen, 1952; Jencks and others, 1956; Schlegel, Behrend, and Eggstein, 1956; Laurell, 1956).

It is generally thought that the increase in the alpha globulin is associated with the early inflammatory exudative stage of rheumatoid arthritis, whereas the increase in gamma globulin appears later during the chronic fibrotic stage (Olhagen, 1952; Ropes and others, 1954; Bonomo, 1957).
An analysis of the results in our own cases of rheumatoid arthritis, though not acceptable as a series in themselves, furnishes some support for the published data of other workers. The rise in the alpha globulins was most marked in the acutely-ill patient at the onset of the disease, the gamma globulin rise dominating the field in the chronic and moderately-ill patient. There is some evidence in our data to support the idea that the rise in alpha globulin completely subsides as the condition becomes chronic (fibrotic). Four out of the ten patients with rheumatoid arthritis, in whom a rise of gamma globulins was the sole abnormality of the protein pattern, were only moderately ill and had suffered from the disease for some years.

Our series of patients with Reiter's syndrome covered a wide range in respect of severity and duration, and therefore the rarity of a significantly raised gamma globulin is noteworthy. In the individual case, electrophoretic analysis may not be of great value in differentiating rheumatoid arthritis from Reiter's syndrome, but the results of larger series give sufficiently distinct patterns to support those who wish to regard the two conditions as separate entities.

\section{Summary}

Electrophoretic serum protein estimations if thirty patients with Reiter's syndrome, ten patients with rheumatoid arthritis, and 27 healthy controls are presented.

The most consistent protein pattern in Reiter's syndrome showed hypo-albuminaemia and a raised alpha globulin. These findings are thought to be characteristic for the condition, though not specific. Beta and gamma globulins were less markedly or consistently elevated. The pattern was distinct from that found in rheumatoid arthritis in the present investigation.

The degree of albumin and alpha globulin changes showed a positive correlation with the severity rather than the duration of the illness, the abnormal protein values tending to return to normal during convalescence. In one patient, however, the ab- 공 normal pattern persisted for a year after the attack $\frac{D}{0}$ had subsided. The changes in the globulin fractions preceded those in the albumin fractions. N

Correlation with the erythrocyte sedimentation rate was close in the active stages of the syndrome and less close during convalescence.

We wish to thank Dr. G. L. M. McElligott for his 0 interest and for permission to use the case material.

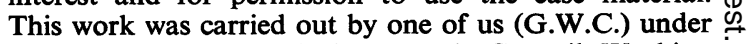
the aegis of the Medical Research Council Working

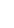

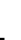

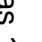

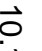

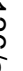


Party on Non-specific Urethritis, with the aid of a grant from the United States Public Health Service.

\section{REFERENCES}

Antweiler, H. J (1957). "Die quantitative Electrophorese in der Medizin", 2nd ed. Springer, Berlin.

Balboni, V. G., and Kydd, D. M. (1952). "Rheumatic Diseases", p. 77. Philadelphia.

Bonomo, L. (1957). Ann. rheum Dis., 16, 340.

Browning, J. S., Rice, R., and Ulrich, C. (1951). Amer. J. med. Sci., 221,183 .

Csonka, G. W (1958). Brit. med. J., 1, 1088

Durrum, E. L. (1956). In "Ciba Foundation Symposium on Paper Electrophoresis". Churchill, London.

Grassmann, W., Hannig, K., and Knedel, M. (1951). Dtsch. med. Wschr., 76, 333 .

Hench, P. S., and Boland, E. W. (1946). Ann. intern. Med.. 24, 808 and ten others (1948). Ibid., 28, 77.

Hunt, T. E., and Trew, J. A. (1954). Ann. rheum. Dis., 13, 201.

Jayle, M. F. (1946). Presse méd., 54, 281.

Jencks, W. P.. Smith, E. R. B., and Durrum, E. L. (1956). Amer. J. Med., 21, 387.

Kawerau, E. (1954). Analyst, 79, 681

Kohn, J. (1957). Clin. chim. Acta, 2, 297.

Laurell, H. (1956). In "Ciba Foundation Symposium on Paper Electrophoresis", p. 58. Churchill, London.

Layani, F., Bengui, A., and Mende, S. de (1952). Sem. Hôp. Paris, 28,3221 .

Olhagen, B. (1952). "Rheumatic Diseases. Based on the Proceedings of the VII International Congress", p. 365. Saunders, Philadelphia.

Ropes, M. W., Perlmann, G. E., Kaufman, D., and Bauer, W. (1954) J. clin. Invest., 33, 311.

Schlegel, B., Behrend, T., and Eggstein, M. (1956). Arztl. Wschr., 11, 1101 .

Stary, Z., Bodur, H., and Batiyok, F. (1951). Schweiz. med. Wschr., 81,1273 .

Svartz, N., and Olhagen, B. (1948). Acta med. scand., 130, Suppl 206, p. 456.

Wallis, A. D. (1950). Ann. intern. Med., 32, 63.

Analyse électrophorétique des protéines sériques dans le syndrome de Reiter

\section{RÉSUMÉ}

On procéda à l'étude électrophorétique des protéines sériques chez 30 malades atteints de syndrome de Reiter, 10 d'arthrite rhumatismale et 27 témoins.

L'hypo-albuminémie et la globuline alpha augmentée constituèrent le trait le plus constant des protéines dans le syndrome de Reiter. On croit que ce trait est carac- téristique, mais non pas spécifique, de cette affection. L'augmentation des globulines beta et gamma fut moins prononcée et moins fréquente. Le tableau fut différent de celui trouvé dans l'arthrite rhumatismale dans le travail présent.

L'intensité des altérations des chiffres d'albumine et de globuline alpha revela une corrélation positive avec la sévérité plutôt qu'avec la durée de la maladie, ces chiffres tendant à devenir normaux pendant la convalescence. Chez un malade, cependant, le tableau anormal persista un an après la fin d'une attaque. Les altérations de la globuline précédèrent celles de l'albumine.

Il y eut une corrélation étroite avec la vitesse de sédimentation érythrocytaire à la période active du syndrome et moins étroite pendant la convalescence.

\section{Análisis electroforético de proteinas séricas en el sindrome de Reiter \\ SUMARIO}

Se estudiaron los rasgos electroforéticos de las proteinas séricas en 30 enfermos con el sidrome de Reiter, 10 con artritis reumatoide y 27 testigos.

La hipo-albuminemia y la globulina alfa aumentada constituyeron el rasgo más constante de la proteinas en el sindrome de Reiter. Se cree que este rasgo es característico, pero no específico, de este sindrome. La elevación de las globulinas beta y gama fué menos pronunciada y menos frecuente. El cuadro fué diferente del encontrado en la artritis reumatoide en esta investigación.

La intensidad de las alteraciones en las cifras de albumina y de globulina alfa reveló una correlación positiva más bien con la severidad que con la duración de la enfermedad, tendiendo estas cifras hacia la normalidad durante la convalecencia. En un enfermo, sin embargo, el cuadro anormal persistió un año después un ataque. Las alteraciones de la globulina precedieron las de la albumina.

Hubo una correlación estrecha con la velocidad de la sedimentación eritrocitaria durante el período activo del sindrome y menos estrecha durante la convalecencia. 